\title{
Osteoid Osteoma of the Big Toe Mimicking Epidermal Inclusion Cyst, A Case Report And Review of The Literature
}

\author{
Latifa Al Manae ${ }^{1}$, Amani Joudeh ${ }^{2}$, Ahmed Mohamed Aly ${ }^{3}$ and Emad Al Absi ${ }^{1}$ \\ ${ }^{1}$ Department of orthopedics, King Fahad specialist hospital, Saudi Arabia \\ ${ }^{2}$ Department of pathology and laboratory medicine, King Fahad specialist hospital, Saudi Arabia \\ ${ }^{3}$ Medical imaging department, King Fahad specialist hospital, Saudi Arabia, Radiology Department National Cancer Institute, Cairo University, Egypt
} Submission: March 19, 2017; Published: March 27, 2017

*Corresponding author: Emad Al Absi, King Fahad Specialist hospital Dammam 32253 Saudi Arabia, Tel: 00966542554768; Email: eeabsi@yahoo.com

\section{Summary}

Osteoid osteoma of the small bones of the foot often cause a diagnostic dilemma due to its rare presentation in these bones as well as to the clinical presentation of pain, redness, swelling and warmth, favoring the physician to think of infection in many of the cases reviewed, though in our case report it was initially suspected to be as an inclusion epidermoid cyst.

\section{Abstract}

Osteoid osteoma is a benign bone forming tumor that makes up $10-12 \%$ of all the benign bone tumors. This tumor favors the long bones of lower extremities as in the femur and tibia, though it can be found elsewhere as in the upper extremities and spine. Osteoid osteoma in the hand and foot are considered rare and uncommon. We are presenting a case report of a 17 years old gentleman presenting with right big toe pain, swelling, and erythema of 18-month duration without antecedent history of trauma and was Initially referred to our clinic with the diagnosis of inclusion epidermoid cyst. The patient was treated surgically by curettage and specimen was sent for histopathology that showed typical histopathological features of osteoid osteoma. Upon follow up for a year post surgery he is completely pain free and radiographs didn't show any evidence of recurrence.

Keywords: Osteoid osteoma; Hallux; Phalanx; Great Toe; Inclusion Epidermoid Cyst

Abbreviations: RFA: Radiofrequency Ablation; MRI: Magnetic Resonance Image; CT: Computed Tomography; NSAIDs: Non-steroidal antiinflammatory drugs

\section{Introduction}

Osteoid osteoma is a benign osteoblastic tumor that was first described by Bergstrand a German physician in 1930 [1]. While Jaffe described it in 1935 and was the first to recognize it as a unique entity as a benign bone tumor [2].

The patients typically present with nocturnal pain relieved by nonsteroidal anti-inflammatory medication and on radiographs it shows a central lucent area that may show minute calcification within it, surrounded by reactive sclerotic bone.

The tumor most commonly occurring in the second decade of life, with more than $50 \%$ of cases are found in the long bones of lower extremities and it can either be cortical, intramedullary or subperiosteal [3]. The foot is a rare location of such tumor and few cases has been reported in the literature and even more rare to find it at the tip of distal phalanx of the big toe which makes it difficult to be diagnosed as osteoid osteoma causing a delay in the treatment. Brodie's abscess, inclusion epidermoid cyst, small sized osteoblastoma, stress fracture, cortical based osteosarcoma, intracortical hemangioma are all in the differential diagnosis of osteoid osteoma in the toes.

\section{Case Report}

We are reporting a case of osteoid osteoma of the terminal phalanx of the big toe in a patient who was referred to us as inclusion epidermoid cyst. He is A 17 years old male complaining of right big toe pain, and swelling of 18-month duration, which was disturbing his sleep due to night pain without a preceding history of trauma. Medical help was sought, and the lesion was initially diagnosed as inclusion epidermoid cyst for further management. Clinical examination showed swollen tip of the 
right big toe with minute overlying ulcer and tender subungual area. All laboratory tests are all within normal limits. Radiograph of the hallux showed a small lucent area at the tip of the distal phalanx with central calcification surrounded by sclerotic bone at some areas (Figure 1-A). MRI showed subungual cystic lesion in the distal phalanx of the right hallux with surrounding bone and soft tissue edema consistent with inclusion epidermoid cyst (Figure 2-B). The patient underwent surgery for open biopsy and curettage of lesion. Histopathology was consistent with osteoid osteoma (Figure 2). Patient was pain free post-operative and his wound have healed nicely. Clinical and radiological follow up of the patients showed complete pain relief and no evidence of recurrence a year following surgery.

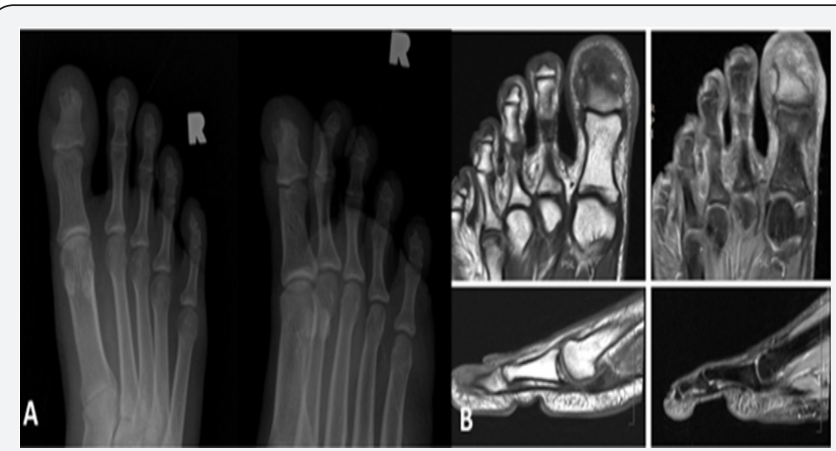

Figure 1: A-Plain radiographs of the big toes showed the lesion with small lucent area at the of the distal phalanx with central calcifications surrounded by sclerosis. B - MRI of the big toe showed subungual cystic lesion in the distal phalanx of the right hallux with surrounding bone and soft tissue oedema consistent with inclusion epidermoid cyst.

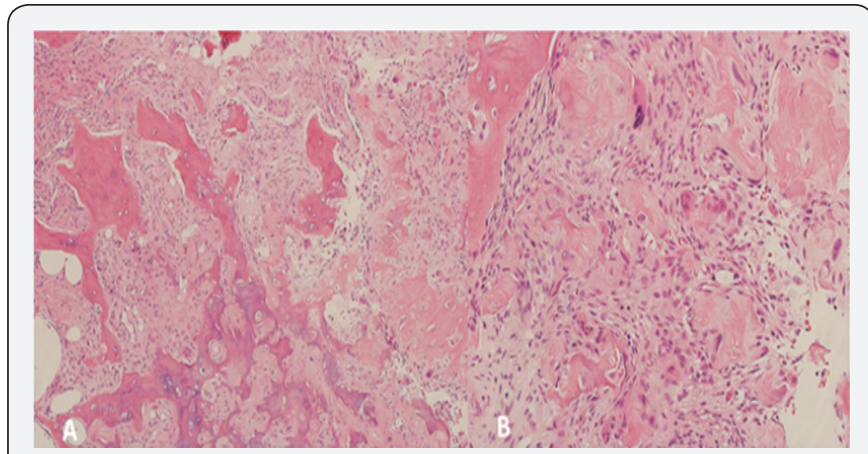

Figure 2: $A$ and $B$ sections reviled reactive bone pieces, some of which are newly formed and young with an obvious nidus formation with anastomosing bone trabeculae and few osteoblastic proliferation consistent with osteiod osteoma.

\section{Discussion}

Osteoid osteoma was first described by the German physician Dr. Bergstrand [1] in 1930 and in 1935 it was described as a benign bone tumor by the American pathologist Dr. HenryJaffe [2]. This benign bone forming tumor represents $10-12 \%$ of all benign bone tumors, with male to female ratio of 3:1. More than $80 \%$ occurring between the ages 5 to 25 years. Commonly affecting the long bones of the lower extremities ( $>50 \%$ ), other common areas are the posterior vertebral elements and the upper extremities [4]. The incidence is $2-11 \%$ in the ankle and foot [5], with the talus being the most commonly affected bone in the foot [6]. Other bones of the foot are less frequently involved, including the calcaneus $(2.7 \%)$, phalanges $(2 \%)$ and metatarsals (1.7\%) [7]. Jaffe et al described in his first publication only one case of osteoid osteoma occurring in the middle toe of the right foot (Jaffe, 1935) [8].

Review of the English-language studies published between 1947 and 2012 showed only 27 cases of osteoid osteoma in the phalanges of the toe reported, of them 13 were in the great toe (four in the proximal and nine in the distal phalanges). The most common location was the great toe, while the fifth toe was the least frequent location [9].

When it comes to the clinical presentation, osteoid osteoma has a characteristic pain pattern often being compared to a toothache, and of being non-mechanical, dull aching in nature with characteristic night pain that is relieved by the use of NSAIDs, however, several case reports have suggested that the most characteristic clinical features of osteoid osteoma in the phalanx of the toes are soft tissue swelling, aching pain [10-12], and erythema $[10,13,14]$.

Radiologically, the typical osteoid osteoma lesion has a very distinctive lucent nidus usually $<1-1.5 \mathrm{~cm}$ surrounded by sclerotic bony reaction while radiologic appearance of osteoid osteoma involving the small bones of the foot is unique with less osteosclerosis and with more soft tissue swelling. On MRI, the lesion may demonstrate bone and soft tissue edema secondary to prostaglandin induced inflammation. Bone scan is extremely sensitive for detecting osteoid osteoma [15] and can help to localize the nidus, especially in patient presenting with referred pain with difficulty in pointing out the source of pain.

Microscopically the nidus is composed of interlacing network of osteoblast-lined trabeculae with inter-trabecular stroma rich with vascular tissue and sometimes times calcification in the centre may be present. This is surrounded by the reactive sclerotic bone. Electron microscopy have shown the presence of nerve ending within the nidus.

Surgical excision of the nidus has been the gold standard of the treatment of osteoid osteoma [16], and it also gives the advantage of the lesion being examined under the microscope and confirmed histologically, and has a lower rate of recurrence compared to other methods. Other methods have been used for treating osteoid osteoma including CT-guided burr ablation, CTguided or fluoroscopy guided radiofrequency ablation (RFA), which was first described by Rosenthal et al. as a treatment for osteoid osteoma [17]. RFA sounds very attractive especially when the lesion is present in an area difficult to be reached with open surgery, with high primary success rate of $90-97 \%$ $[18,19]$. Surgical excision was the method of treatment in our case as it was initially diagnosed as inclusion epidermoid cyst 
and nevertheless would have been treated the same as these tumors in such location are very small and can only approached by surgical excision.

\section{Conclusion}

Osteoid osteoma should be considered in the differential diagnosis when a patient presents with pain and swelling in the toes, especially when there is a history of improvement of pain even partially with use of NSAIDs. Osteoid osteoma in the phalanges may not have the typical radiographic sclerosis surrounding the nidus due to its endosteal and subperiosteal location. These knowledges can help in reaching of diagnosis and relieving the pain without patient undergoing unnecessarily treatment (ex. antibiotic for osteomyelitis or soft tissue infection).

\section{References}

1. Bergstrand H (1930) Ubereineeigenartige, wars cheinlichbishernicht be schrie beneos teoblastische Krankheit in den langen Knochen in der Hand und des Fusses. Acta Radiol 11: 596-613.

2. Henry L Jaffe (1935) Osteoid osteoma. A benign osteoblastic tumour composed of osteoid and atypical bone. Arch Surg 31(5): 709-728.

3. Edeiken J, De Palma AF, Hodes PJ (1966) Osteoid osteoma: roentgenographic emphasis. Clin Orthop Relat Res 49: 201-206.

4. Orthopaedic Knowledge Update: Musculoskeletal Tumors 3, Editor L Sybil Biermann, MD AAOS (chapter 11).

5. Freiberger RH, Loitman BS, Halpern M, Thompson TC (1959) Osteoid osteoma; A report of 80 cases. Am J Roentgenol Radium Ther Nucl Med 82(2): 194-205.

6. Shukla S, Clarke AW, Saifuddin A (2010) Imaging features of foot osteoid osteoma. Skeletal Radiol 39(7): 683-689.

7. Jackson RP, Reckling FW, Mants FA (1977) Osteoid osteoma and osteoblastoma. Clin Orthop Relat Res 128: 303-313.
8. Jaffe HF (1935) Osteoid osteoma. A benign osteoblastic tumour composed of osteoid and atypical bone. Arch Surg 31(5): 709-728.

9. Turkmen I, Alpan B, Soylemez S, Ozkan FU, Unay K, et al. (2013) Osteoid Osteoma of the Great Toe Mimicking Osteomyelitis: A Case Report and Review of the Literature. Case Rep Orthop 2013: 234048.

10. Tsang DS, Wu DY (2008) Osteoid osteoma of phalangeal bone. J Formos Med Assoc 107(7): 582-586.

11. LaCroix ML, Thomas JR, Nicholas RW (2001) Subperiosteal osteoid osteoma of the distal phalanx of the fourth toe. Orthopedics 24(7): 695-669.

12. Renò F, Grazianetti P, Cannas M (2001) Effects of mechanical compression on hypertrophic scars: prostaglandin E2 release. Burns 27(3): 215-218.

13. Ebrahimzadeh MH, Omidi-Kashani F, Hoseini MR (2009) Painful and tender toe, osteoid osteoma of the distal phalanx of toe, a diagnostic dilemma. Foot (Edinb) 19(4): 232-235.

14. Jowett CR, Singh D(2010) Osteoid osteoma of the great toe: A case report. Foot Ankle Surg 16(2): 12-15.

15. Bilchik T, Heyman S, Siegel A, Alavi A (1992) Osteoid osteoma: The role of radionuclide bone imaging, conventional radiography and computed tomography in its management. J Nucl Me 33(2): 269-271.

16. Campanacci M, Ruggieri P, Gasbarrini A, Ferraro A, Campanacci L (1999) Osteoid osteoma. Direct visual identification and intralesional excision of the nidus with minimal removal of bone. J Bone Joint Surg Br 81(5): 814-820.

17. Rosenthal DI, Alexander A, Rosenberg AE, Springfield D (1992) Ablation of osteoid osteomas with ercutaneously placed electrode: a new procedure. Radiology 183(1): 29-33.

18. Dierselhuis EF, Jutte PC, van der Eerden PJ, Suurmeijer AJ, Bulstra SK (2010) Hip fracture after radiofrequency ablation therapy for bone tumors: Two case reports. Skeletal Radiol 39(11): 1139-1143.

19. Ward E, Munk PL, Rashid F, Torreggiani WC (2008) Musculoskeletal interventional radiology: Radiofrequency ablation. Radiol Clin North Am 46(3): 599-610.

\section{Your next submission with Juniper Publishers} will reach you the below assets

- Quality Editorial service

- Swift Peer Review

- Reprints availability

- E-prints Service

- Manuscript Podcast for convenient understanding

- Global attainment for your research

- Manuscript accessibility in different formats

( Pdf, E-pub, Full Text, Audio)

- Unceasing customer service

Track the below URL for one-step submission https://juniperpublishers.com/online-submission.php 